\title{
SEROPREVALENCE OF ANTIBODIES TO CHLAMYDOPHILA ABORTUS IN OVINE IN THE STATE OF
}

\section{ALAGOAS, BRAZIL}

\section{José Wilton Pinheiro Junior ${ }^{1}$; Rinaldo Aparecido Mota ${ }^{2 *}$; Rosa Maria Piatti ${ }^{3}$; Andréa Alice da Fonseca Oliveira ${ }^{2}$; Aline} Melo da Silva ${ }^{4}$; Sílvio Romero de Oliveira Abreu ${ }^{4}$; Giulliano Aires Anderlini ${ }^{4}$ : Rômulo Menna Barreto Valença ${ }^{4}$

${ }^{1}$ Unidade Acadêmica de Garanhuns, Universidade Federal Rural de Pernambuco, Garanhuns, PE, Brasil; ${ }^{2}$ Departamento de Medicina Veterinária, Universidade Federal Rural de Pernambuco, Garanhuns, PE, Brasil; ${ }^{3}$ Centro de Pesquisa e Desenvolvimento de Sanidade Animal, Instituto Biológico, São Paulo, SP, Brasil; ${ }^{4}$ Centro de Estudos Superiores de Maceió, Faculdade de Ciências Biológicas, Centro de Estudos Superiores de Maceió, Faculdade de Ciências Biológicas, Maceió, AL, Brasil.

Submitted: August 05, 2008; Returned to authors for corrections: September 02, 2008; Approved: November 07, 2009.

\begin{abstract}
The goal of this study was to perform a seroepidemiological investigation and to identify risk factors associated with infection of Chlamydophila abortus of sheep herds in the Brazilian state of Alagoas. The study was conducted with samples of 274 ewes with ages equal to or higher than 24 months in 25 herds and in 23 towns located in three regions of the state (Sertão, Agreste and Eastern Alagoas). Anti-C. abortus antibodies were detected using the microcomplement fixation test. The risk factors, were determined based on questionnaires consisting of objective questions, about the farmer and general characteristics of the herd like size, sanitary situation and reproductive management. Among 274 sera samples analyzed for C. abortus, $59(21.5 \%)$ were positive with titers $\geq 32,187$ (68.3\%) negative and $28(10.2 \%)$ suspect with titers $\geq 16$. In the 23 towns studied, 20 had positive animals. Among herds 21 (77.7\%) of had positive animals. The only variable which appeared to be significant in the multivariate analysis was the region, and Sertão was the most significant $(\mathrm{p}<0.001 ; \mathrm{OR}=3.48$; T.I. $1.79-6.76)$. Results indicate that infection by Chlamydophila abortus is widespread on sheep farms in the State of Alagoas. Others studies, however, have to be conducted to isolate the agent in order to confirm the role of the bacteria is reproductive disturbances in sheeps. In addition to that, control and prophylactic measures along with health promoting programs have to be encouraged on the studied farms so that infection reates are reduced.
\end{abstract}

Key words: diagnosis, chlamydiosis, serum epidemiology

\section{INTRODUCTION}

Ovine enzootic abortion (OEA) caused by Chlamydophila abortus is the most prominent cause of reproductive defects in most countries producing sheep (1). Once the disease reaches epidemic proportions, up to $30 \%$ of ewes can abort in the last three weeks of gestation, give birth prematurely or give birth to weak lambs. After the abortion, ewes develop protective immunity. In the endemic form of the disease, abortions have been observed in roughly $5-10 \%$ of ewes of each affected herd $(3,22)$. 
The principal source of infection in the environment is placentas or fetal fluids of infected animals. Experimental findings suggest that venereal transmission is a less common form of transmission (4).

The development of clinical signals of chlamydiosis depends on the time period of infection. Sheep and goats infected 5-6 weeks before giving birth can develop the clinical disease during their current gestation (18). Animals infected during the last four weeks of gestation can develop a latent infection; clinical signs then appear during the next gestation (25). It has been shown that the reproductive organs of ewes and goats suffering from a latent infection can contain $C$. abortus even after more than 3 years after the infection (18). Lambs and kids delivered by infected animals are generally weak and die a few days after birth (3).

While - as is the case with other ovine reproduction diseases - the introduction of the agent on a hitherto unaffected farm triggers serious pathological processes with a high morbidity and mortality, a prolonged contact with the agent leads to tolerance as the disease assumes an enzootic character (10).

The data on prevalence of $C$. abortus infection across the world reveal that rates vary from $11.9 \%$ (15) to $48.2 \%$ (17). In Brazil, serological assessments of infections caused by this bacterium in small ruminants are rare. The works conducted by Piatti et al. (21) in São Paulo state and by Pereira (20) in Pernambuco state stand out. The former obtained positive results only in goats and the latter confirmed the presence of anti-C. abortus antibodies in goats $(12,0 \% / 167)$ and sheep $(8,1 \% / 123)$, which was the first recorded case of infection in sheep in Brazil.

Some risk factors were identified for sheep. They are primarily the type of animal production, proximity to other farming establishments, animal replacement policy, frequency of abortions, undernourishment, overpopulation, transport and subclinical bacterial and parasitic diseases (10).

Considering the importance of chlamydiosis for both animal and public health and the scarcity of epidemiologic data about the presence of the infection in sheep in the north-eastern part of the country, the goal of this study is to perform a seroepidemiological investigation and to identify risk factors associated with infection by Chlamydophila abortus of sheep herds in the Brazilian state of Alagoas.

\section{MATERIAL AND METHODS}

Alagoas state is situated in the central-eastern part of the Brazilian North-East region and extends between $8^{\circ} 48^{\prime} 12^{\prime \prime}$ and $10^{\circ} 30^{\prime} 12^{\prime \prime}$ south latitude and between $35^{\circ} 09^{\prime} 36^{\prime \prime}$ and $38^{\circ} 13{ }^{\prime} 54^{\prime \prime}$ west longitude. For administrative purposes, it is divided in three mesoregions, namely Leste Alagoano, Agreste Alagoano e Sertão Alagoano, and in 13 microregions which are Serrana do Sertão Alagoana, Alagoana do Sertão do São Francisco, Santana do Ipanema, Batalha, Palmeira dos Índios, Arapiraca, Traipu, Serrana dos Quilombos, Mata Alagoana, Litoral Norte Alagoano, Maceió, São Miguel dos Campos and Penedo, which contain a total of 102 towns that together form this federal state, whose capital is Maceió $(24,5)$.

Sera samples of 274 ewes with ages equal to or higher than 24 months in 27 herds and in 23 towns were studied. The animals were subjected to an extensive, intensive and semiintensive rearing system and the prevailing races were Santa Inês, Dorper and crosses. The animals were fed native grass, concentrated feed and mineral salt.

The examination of anti-Chlamydophila antibodies was conducted in Bacterial Reproduction Disease Laboratory of the São Paulo Biology Institute using the technology of microcomplement fixation test (11), a method recommended by the Office International des Epizooties (19). The reaction was conducted in microplates using test serum diluted of 1:16 to 1:512, antigen $C$. abortus CEPA S26/3 diluted 1:50 and the complement in the corresponding dilution to two fixating units of complement. After incubation at $37^{\circ} \mathrm{C}$ for $30 \mathrm{~min}$. the hemolytic system was added to the microplates incubated for $30 \mathrm{~min}$, and the microplates were centrifuged at $3000 \mathrm{rpm}$ for 5 $\min$. The results were read visually.

Bovine serum with titer of 1:512 obtained from Institute of Zooprofilattico Sperimentalle delle Venezie Itália- IZSV and Fetal bovine serum were used as positive and negative controls, respectively. The titer of antibody was defined as the reciprocal 
of the highest serum dilution that presented $50 \%$ complement fixation. The positive end dilution titer was 1:32 or higher and 1:16 was considered suspected (11).

For the study of risk factors, farmers were asked to respond questionnaires with objective questions on general characteristics of their herds, sike size, sanitary situation and reproductive management.

To identify risk factors associated with the infection by $C$. abortus, an univariate analysis by means was conducted for the variables of interest. When necessary, the Pearson's Chi-square test or Fisher's exact test was reformed. A multivariate analysis was done with the model of logistic regression considering the serological status of the animal (positive or negative) for Chlamydophila abortus as a dependent variable. The independent or explanatory variables considered in the model were those that showed a statistical significance $<0,20$. This probability was stipulated so that possible risk factors of the event were not excluded from the analysis (13). Statistical calculations were done usig the SPSS for Windows program, version 12.0 - Statistical Package for the Social Science.

\section{RESULTS AND DISCUSSION}

Among 274 sera analyzed by RFC, 59 (21.5\%) were positive for Chlamydophila abortus with titers $\geq 32,187$ $(68.3 \%)$ were negative and $28(10.2 \%)$ were suspect with titer $\geq 16$. Some papers done in other countries have estimated prevalences ranging from 5.00 to $39.0 \%$, in which the latter is considered high $(3,6)$. A retrospective study conducted in Italy between 1993 and 2003 showed a prevalence ranging from 21.0 to $46.8 \%$ (16). Prevalence observed in sheep in the State of Alagoas can be thus considered high and studies must be encouraged to elucidate the participation of this bacterium in reproductive disturbances in the region under study.

The first report of the presence of anti-C. abortus antibodies in sheep in Brazil was described by Pereira (20) in the State of Pernambuco, who found a frequency of $8.1 \%$ of serum reagent sheep. In the State of Alagoas this is the first record of the presence of anti-C. abortus antibodies in sheep.

A relative high percentage of suspect animals was also observed. These animals may have been infected, presenting titers of antibodies that would increase with time, increasing the prevalence rates detected in this study. The cross relation between $C$. abortus and $C$. pecorum can explain false-positive results with low titers. Thus, titers lower than 1:32 in individuals must be considered unspecific for C. abortus (19). In Brazil, there are no reports of sheep infection by $C$. pecorum, however, this agent is endemic in ruminants in several countries, causing symptoms such as polyarthritis, keratoconjunctivitis, encephalomyelitis and intestinal infections in cattle and sheep, as well as pneumonia and miscarriage in sheep (7).

Among the 23 towns studied, 20 (86.9\%) had animals with titer $\geq 32$ of anti-Chlamydophila abortus antibodies. In three $(13.1 \%)$ towns, serum reagent sheep were not detected. Considering the number of properties analyzed, $77.77 \%$ of them had serum reagent animals with a titer $\geq 32$ and $22.22 \%$ with a titer lower than 16 , considered negative (Table 1).

Table 1. Relative frequency of anti-Chlamydophila abortus antibodies in sheep distributed per towns and properties in the State of Alagoas, Brazil, 2008

\begin{tabular}{lcccc}
\hline Titer of antibodies & Towns & Relative frequency (\%) & Properties & Relative frequency (\%) \\
\hline$<16$ & $3 / 23$ & 13.1 & $6 / 27$ & 22.2 \\
$>16$ & $13 / 23$ & 56.5 & $14 / 27$ & 51.8 \\
$\geq 32$ & $20 / 23$ & 86.9 & $21 / 27$ & 77.7 \\
\hline
\end{tabular}


Frequency of infection of sheep by $C$. abortus ranged between 1.0 and $62.5 \%$ in the towns and between $5.88 \%$ and $66.66 \%$ in the properties. One can thus infer this infection is widespread in the regions under study. However, the definitive diagnosis depends on the detection of the agent, by cell cultivation or polymerase chain reaction (PCR).

Pereira (20) in the State of Pernambuco, Brazil, evaluated goats and sheep by serological tests and reported a frequency ranging from $4.0 \%$ to $60.0 \%$ in 12 positive properties for $C$. abortus. In $91.60 \%$ of the properties, at least one positive animal was found, indicating that there are several foci of infection and that infection is widespread in the region.

In the univariate analysis, a significant association was found for the variables region and common water trough for young and adult animals (Table 2). However, in the multivariate analysis the only factor that showed a significant association was region (Table 3 ).

Table 2. Risk factors according to region, production characteristics and hygienic and sanitary handling associated with infection by Chlamydophila abortus in sheep in the State of Alagoas, Brazil, 2008

\begin{tabular}{|c|c|c|c|c|}
\hline \multirow{2}{*}{ Variable } & \multirow{2}{*}{$\mathbf{N}$} & \multirow{2}{*}{$\begin{array}{l}\text { CFR } \\
\text { n }(\%)\end{array}$} & \multicolumn{2}{|c|}{ Univariate Analysis } \\
\hline & & & OR (T.I. 95\%) & $\mathbf{P}$ \\
\hline \multicolumn{5}{|l|}{ Region } \\
\hline East & 144 & $19(13.2)$ & 1.0 & $0.001 *$ \\
\hline Agreste & 49 & $12(24.5)$ & $2.13(0.95 ; 4.79)$ & \\
\hline Sertão & 81 & $28(34.6)$ & $3.48(1.79 ; 6.79)$ & \\
\hline \multicolumn{5}{|l|}{ Size of property (ha) } \\
\hline$<30$ & 35 & $8(22.9)$ & 1.0 & 0.516 \\
\hline Between 30 and 200 & 101 & $18(17.8)$ & $0.73(0.29 ; 1.87)$ & \\
\hline Above 200 & 138 & $33(23.9)$ & $1.06(0.44 ; 2.56)$ & \\
\hline \multicolumn{5}{|l|}{ Number of animals (head) } \\
\hline$<50$ & 82 & $18(22.0)$ & 1.0 & 0.570 \\
\hline Between 50 and 100 & 89 & $22(24.7)$ & $1.17(0.57 ; 2.38)$ & \\
\hline Above 100 & 103 & $19(18.4)$ & $0.80(0.39 ; 1.66)$ & \\
\hline \multicolumn{5}{|l|}{ Rearing system } \\
\hline Intensive & 40 & $13(32.5)$ & 1.0 & 0.189 \\
\hline Extensive & 72 & $14(19.4)$ & $0.50(0.21 ; 1.21)$ & \\
\hline Semi-intensive & 162 & $32(19.8)$ & $0.51(0.24 ; 1.10)$ & \\
\hline \multicolumn{5}{|l|}{ Water source } \\
\hline Still & 69 & $21(30.4)$ & 1.0 & 0.108 \\
\hline Running & 92 & $16(17.4)$ & $0.48(0.23 ; 1.01)$ & \\
\hline Still + Running & 113 & $22(19.5)$ & $0.55(0.28 ; 1.11)$ & \\
\hline \multicolumn{5}{|l|}{ Feeding } \\
\hline With supplementation & 56 & $11(19.6)$ & 1.0 & 0.701 \\
\hline Without supplementation & 218 & $48(22.0)$ & $1.15(0.55 ; 2.40)$ & \\
\hline \multicolumn{5}{|c|}{$\begin{array}{l}\text { Common water troughs for young and } \\
\text { adult animals }\end{array}$} \\
\hline No & 6 & $4(66.7)$ & 1.0 & $0.021 *$ \\
\hline Yes & 268 & $55(20.5)$ & $0.13(0.02 ; 0.72)$ & \\
\hline
\end{tabular}


Table 3. Multivariate analysis for risk factors associated or not with infection by Chlamydophila abortus in sheep in the State of Alagoas, Brazil, 2008.

\begin{tabular}{|c|c|c|c|c|}
\hline Variable & Coefficient & p-value & $\begin{array}{l}\text { Odds } \\
\text { Ratio } \\
\end{array}$ & T.I. 95\% \\
\hline Region & & 0.001 & & \\
\hline Sertão & 1.25 & $<0.001$ & 3.48 & {$[1.79 ; 6.76]$} \\
\hline Agreste & 0.76 & 0.067 & 2.13 & {$[0.95 ; 4.80]$} \\
\hline Constant & -1.88 & $<0.001$ & & \\
\hline
\end{tabular}

T.I. - Trust Interval

The frequency of positive animals per region was $34.6 \%$ for Sertão, 24.5\% for Agreste and 13.2\% for Eastern Alagoas. Animals from the Sertão have approximately 3.5 times more chances of being infected by $C$. abortus than animals from other two regions. Animals from the Agreste, have 2 times more changes of being infected than animals from Eastern Alagoas. These results are difficult to explain as there are gaps in knowledge on the epidemiology of mammal chlamydophilosis, particularly regarding intra and interspecies transmission (10). On the other hand, Alagoas state borders the states of Pernambuco, Bahia and Sergipe (Brazil) and animal roaming between these states is frequent, which could contribute to the dissemination of this infection. More thorough epidemiological studies are thus needed to verify the presence of possible vectors or domestic and wild hosts that could be contributing to a higher frequency of positive animals in the sertão of Alagoas.

Another variable that should be stressed is the use of common water troughs for young and adult animals. Even though this practice did not show a significant association in the multivariate analysis, $20.5 \%$ of serum reagent animals were raised in properties that adopted this practice. The most common sources of infection for sheep are miscarried fetuses, placenta and vaginal discharge (23). Still water and contaminated food can thus be a source of infection in the intensive and semi-intensive system. Water source did not show a significant association; however, more serum reagent animals were observed in properties that provided water from dams and wells $(30.4 \%)$ compared to the others.
Regarding rearing system, even though a significant association was not observed between the systems in use, more serum reagent animals were observed in the intensive system. According to Igayara-Souza et al. (14), for cattle the intensive system is a risk factor for the occurrence of chlamydophilosis due to the overpopulation that is often observed on the farms that adopt this kind of rearing system.

The results of risk factors for variables of reproductive handling are found in Table 4. The univariate analysis indicated a significant association only for the variable purchase of spare breeding animals in the last five years $(\mathrm{p}=$ 0,019), which was not confirmed in the multivariate analysis (Table 3). There are few indications of sexual transmission of C. abortus in sheep (23). New studied must be conducted in order to elucidate this variable for a better understanding of the epidemiology of the disease and for the implementation of proper control measures in order to reduce the spreading of the agent.

The association between miscarriages and presence of anti-C. abortus antibodies was not significant in this study, however, it was observed that $20.9 \%$ of serum reagent animals had a history of miscarriages associated with other reproductive disturbances (stillborn, repetition of heat, fetal mummification and retention of placenta). The entry of virulent C. abortus strains in the herd associated with undernourishment, overpopulation and subclinical diseases by bacteria and parasites may determine outbreaks of the disease (10). Eventually, the infection induces immunity that can last years regarding the presentation of miscarriages and, due to 
this immunity, the infection remains latent in females, producing sporadic miscarriages (8). Symptomatology of this disease depends on several factors such as: path of infection, age, sex, environment, handling conditions and other factors associated with virulence of the strain that originates the infection.

According to Silva et al. (23), even though C. abortus is often identified in several countries, mainly in goat and sheep enzootic abortions, in Brazil there are no epidemiological data that demonstrate the participation of this bacterium in reproductive problems in production species. Serological inquests as well as analysis of risk factors are thus important to demonstrate the real participation of $C$. abortus in reproductive disturbances in sheep, as well as to identify which variables are important for the maintenance and dissemination of the agent in herds, which will give feedback to the control and eradication of this disease.

It must also be said that this agent is important for public health since $C$. abortus is a zoonotic agent and according to CFSPH (9) between 1987 and 2000, twenty cases were confirmed in women by this agent.

The prophylaxis of chlamydophilosis like any other infectious disease must be conducted on three levels: handling measures, chemotherapeutic drug administration and use of vaccines (12). Main handling measures are: segregation of women about to give birth and elimination of contaminated materials as well as disinfection of contaminated areas. Up to the moment in Brazil there is not a commercially available vaccine for Chlamydophila abortus (7).

As shown, infection by Chlamydophila abortus is widespread on sheep farms in the State of Alagoas. However, further studies must be conducted to confirm the role of this bacterium in reproductive disturbances in sheep. Furthermore, control and prophylactic measures and continuous education must be encouraged in the properties studied in order to reduce rates of infection.

\section{REFERENCES}

1. Aikten, I.D. (1993). Ovine clamydial abortion. In: Woldehiwet, Z.; Ristic, M. (Eds.), Rickettsial and Chlamydial. Diseases of Domestic
Animals. Pergamon Press: Oxford, p.349-360.

2. Aikten, I.D. (2007). Clamydial abortion. In: Aikten, I.D. Diseases of Sheep. Blackell Science: Oxford, p.247-290.

3. Al-Qudah, K.M.; Sharif, L.A.; Raouf, R.Y.; Hailat, N.Q.; Al-Domy, F.M. (2004). Seroprevalence of antibodies to Chlamydophila abortus shown in Awassi sheep and local goats in Jordan. Vet. Med. - Czech, 12, 460-466.

4. Appleyard, W.T.; Aitken, I.D.; Anderson, I.E. (1985).Attempted veneral transmission of Chlamydia psittaci in sheep. Vet. Rec. 116, 535-538.

5. Assis, J.S.; Alves, A.L.; Nascimento, M.C. (2007). Atlas escolar Alagoas: espaço geo-histórico e cultural. João Pessoa: Grafset, 208p.

6. Borel, N.; Doherr, M.G.; Vretou, E.; Psarrou, E.; Thoma, R.; Pospischil, A. (2004). Seroprevalences for ovine enzootic abortion in Switzerland. Prev. Vet. Med. 65, 205-216.

7. Cardoso, M.V. (2006). Clamidofiloses (clamidioses) em pequenos ruminantes. Biol. 68 (1/2), 11-12.

8. Caro, M.R.; Buendia, A.J.; Gallego, M.C. (1995). Patogenia y cuadros clínicos: Clamidiosis. Trat. Patol. Produc. Ovina. 37, 23-39.

9. CFSPH - The Center for Food Security and Public Health. Zoonotic Clamydiae from Mammals. 2005. Available at: http://www.cfsph.iastate.edu. Accessed: 01 february 2008.

10. Cuello, F.; Caro, M.R.; Salinas, J. (1995). Epidemiologia: Clamidiosis. Trat. Patol. Produc. Ovina, 37, 41-51.

11. Donn, A.; Carnicletto, P.; Chiaracane, G. (1997). Standardizzazione della tecnica di fisazione del complemento per la dimostrazione di anticorpi anti-Chlamydia nel siero di sangue. Prog. Vet. 4, 125-128, 1997.

12. Gallego, M.C.; Salinas, J. (1995). Tratamiento y control: Clamidiosis. Trat. Patol. Produc. Ovina. 37, 71-80.

13. Hosmer, D.W.; Lemeshow, S. (1989). Applied Logistic Regression. New York: John Wiley \& Sons, 241p.

14. Igayara-Souza, C.A.; Genovez, M.E.; Ferreira, F.; Paulin, L.M.; Scarcelli, E. (2004). Ocorrência de anticorpos anti-Chlamydophila abortus em bovinos e avaliação de possível relação com distúrbios reprodutivos em São Paulo-Brasil. Rev. Bras. Reprod. Anim.28 (1), 2833.

15. Mangana, O.; Mastroyanni, M. Enzootic abortion of sheep and goat in Greece. In: Aitken, I.D. Comission of the European Communities. Luxembourg, 1986. p.17.

16. Masala, G.; Porcu, R.; Sanna, G., Tanda, A.; Tola, S. (2005). Role of Chlamydophila abortus in ovine and caprine abortion in Sardinia, Italy. Vet. Res. Commun.29, 117-123.

17. Milon, A.; Pellerin, J.L.; Geral, M.F.; Perol, S.; Lautie, R. (1985). Serologie de la clamidiose ovine par le test ELISA. Utilissation d'un antigene commercial prepare a partir d'une souche de Chlamydia trachomatis. Rev. Med. Vet. 136, 13, 1985.

18. Morgan, K.L.; Wills, J.M.; Howard, P. (1988). Isolation of Chlamydia psittaci from the genital tract of lambs: A possible links with enzootic abortion in ewes. Vet. Rec. 123, 399-400.

19. OIE. Animal Health World Organization. Manual of Diagnostic Tests and Vaccines for Terrestrial Animals Diseases. Available at: 
http://www.oie.int/eng/normes/mmanual. Accessed: 07 february 2008.

20. Pereira, M.F. (2007). Aborto infeccioso em pequenos ruminantes no Estado de Pernambuco: aspectos epidemiológicos, sorológicos, moleculares e anátomo-histopatológicos. Recife, Brasil, 147p. (Dr. Thesis, Universidade Federal Rural de Pernambuco, UFRPE).

21. Piatti, R.M.; Scarcelli, E.P.; Genovez, M.E. (2006). Pesquisa de anticorpos anti-Chlamydophila em caprinos e ovinos. Biol. 68 (2), 138140.

22. Rodolakis, A.; Salinas, J.; Papp, J. (1998). Recent advances on ovine chlamydial abortion. Vet. Res. 29 (3/4), 275-288.

23. Silva, F.G.; Freitas, J.C.; Müller, E.E. (2006). Chlamydophila abortus em animais de produção. Cienc. Rural. 36 (1), 342-348.

24. UFAL/GEM - Universidade Federal de Alagoas. Departamento de geografia e meio ambiente. (1994). Atlas Geográfico de Estado de Alagoas. Maceió: EDUFAL: Ecopres, 44p.

25. Wilsmore, A J.; Dawson, M. (1990). Chlamidial diseases of ruminant in Britain. In: Aitken, D. Agriculture Chlamydial diseases of ruminants. Commission of the European Communities Seminar, p.13-16. 